\title{
Social Change and the Greek Welfare State Crisis (2010-2020)
}

\author{
Nikos Kourachanis, PhD \\ Panteion University of Social and Political Sciences, Athens, Greece \\ iD https://orcid.org/oooo-0001-9034-7902
}

Contact: n.kourachanis@panteion.gr

\begin{abstract}
This article attempts to utilize the concept of social change for the study of transformations in the Greek welfare state during the period of the multiple crises it is currently experiencing (2010-2020). This will be done through an analysis of the changes taking place in the Greek social security system, the backbone of social policy in Greece. The main argument is that, although there are fundamental differences in the development of the Greek welfare state compared to the welfare model of Western European countries, in the last decade there has been a convergence towards a neoliberal model of social policy. The elaboration of this claim will examine those theories of social change that attempt to explain the transition from the Keynesian to the neoliberal welfare state both in the period after 1970 and in the period after the Great Recession of 2008. The development of the Greek social security system over time is then examined, with a particular focus on the decade from 2010-2020. This will show that, despite the different context for the development of the social security system in Greece, the reforms imposed by austerity policies in the last decade have led to a convergence with the model of the neoliberal welfare state. The trend towards residualization and privatization of the social security system with a focus solely on the management of extreme poverty can be observed as one of the mechanisms of social change that are being adopted.
\end{abstract}

Keywords: Social change theories; welfare state; social security; Greece; crisis; neoliberalism

Date Submitted: March 16, 2021 | Date Published: July 29, 2021

Recommended Citation

Kourachanis, N. (2021). Social change and the Greek welfare state crisis (2010-2020). Journal of Social Change, 13, 4557. https://doi.org/10.5590/JOSC.2021.13.2.04

\section{Introduction}

In this article, I present the social changes implicated in the reforms to the Greek social security system that have taken place in the last decade (2010-2020). The term "social security" includes collective forms of intervention that are established to maintain an individual or family income or to provide benefits. This occurs when all or some income sources no longer exist, are not available, or when significant costs need to be addressed (Abel-Smith, 1959). The social security measures offer cash or other in-kind benefits for scenarios such as incapacity to work or unemployment or to meet social needs, such as health services. A social security system is thus often divided into two fundamental subsystems: the social insurance system and the social assistance system (Abel-Smith \& Townsend, 1984). 
The social changes that influenced the formation of the welfare state in Greece differed significantly from those of the welfare state models of Western Europe (Petmesidou, 2006). However, the effects of the Great Recession of 2008 have led to the Greek model following a trend of convergence with the dominant neoliberal model of the welfare state (Dimoulas \& Kouzis, 2018).

The last decade has been marked by a series of abrupt changes in the Greek social security system because of the austerity policies that have been adopted. The Greek state found itself unprepared to handle this unfavorable economic situation. This gave the financial markets an opportunity to attack the Greek state. Consequently, the European Union's (EU's) dominant political forces used debt as a tool of control (Fouskas \& Dimoulas, 2013) and forced the country to adopt methods of "punitive" fiscal discipline.

Greece was driven to requesting international financial assistance. The EU, together with the European Central Bank and the International Monetary Fund, imposed harsh austerity policies on the Greek government (Papatheodorou, 2015). Significant reductions in pensions and welfare benefits, restrictions on social services, the introduction of a fee for access to the national health system, and the general promotion of private health services (Petmesidou, 2017) are some of the extensive rearrangements to the Greek social protection system during the years of the crisis.

Within this painful environment, the concept of social change has specific characteristics that are related to the content of the reforms being promoted. To develop this line of thinking, I first present the relationship between social change and the welfare state. I then examine the Greek case in the past decade, with its multiple social changes, with a focus on the Greek social security system and reform efforts.

\section{Social Change and the Welfare State}

\section{The Emergence of Social Change}

The concept of social change has played a central role in the study of social phenomena since the 19th century. Awareness of the changes taking place at the economic, technological, productive, and environmental levels and, above all, their impact on people's living conditions have led many sociologists to the adoption of this concept (Sztompka, 1993). Social change does not have an a priori positive or negative meaning; this depends instead on the nature of the transformations that are taking place.

Thus, theories of social change over the decades of the 2oth century have mostly focused on the nature of capitalist development and how it is transformed into social development or otherwise. These theories are, therefore, attempts to analyze and understand the transformations that are taking place in capitalist societies, mainly at the macro-level (Abercrombie et al., 1984). As might be expected, the welfare state was not part of the earliest attempts to analyze social change. This is because the first attempts to understand social transformation predate the development of the welfare state in the mid-2oth century (Béland \& Waddan, 2012).

For almost two centuries, the science of sociology has been able to develop many approaches to the concept of social change. This highlights the dynamic nature of approaches to social change, as well as the diversification of social issues (Jimenez et al., 2014). According to Strasser and Randall (1981), social change refers to the difference between before and now. A similar definition describes social change as an attempt to highlight the significant changes that have taken place in the underlying structure of an object or situation over time (Fairclough, 1992).

The main factors that trigger processes of social change in modern societies are economic, political, and cultural influences. In economic effects, significant influences have been exerted by the restructuring of 
industrial and postindustrial capitalism. Capitalism promotes the constant revision of technology and production and is a weighty variable in social change. Political developments also play an important role in bringing about social change. The efforts of supranational and national political leaders to increase their influence and affect decisions in favor of their political agenda are important parameters in activating processes of social change. Finally, developments that extend to the wider realm of cultural norms also affect social change. The reconfiguration of the prevailing values and perceptions around people's daily lifestyles and living conditions can lead to widespread social upheavals (Giddens, 1997; Sztompka, 2000; May, 2011).

But what can social change mean in terms of the welfare state? Does the inherently dynamic nature of social change affect its character? Since the welfare state is formed within organized societies, it is reasonable to expect that it is influenced by the parameters that bring about social change (economic, political, cultural). In recent decades, the debate over new social risks has enriched the dialogue on social change and given it new dimensions. Such issues are the pressures that have been placed on national social protection systems, such as demographic aging, changes in family structure, and the transition to a postindustrial economy (McCashin, 2019).

The spectrum of all these changes can be seen in the transformations made to the character of the welfare state in different historical periods. To understand this issue, I will discuss three interpretive approaches to social change: (1) the Keynesian model of the welfare state; (2) the neoliberal welfare state from the 1970s to 2008; and (3) the neoliberal welfare state from the Great Recession of 2008 until today.

\section{Social Change and the Welfare State Transformations}

During the initial phase of the development of theories of social change in the 19th century, the effect of industrialization on European societies was the focus of study. Analyses such as those by A. Comte, H. Spencer, and E. Durkheim functionally examined the basic stages of the development of societies through an evolutionary theory. In contrast, the approach used by Karl Marx saw social conflict as the spirit that led to social change (Smith, 1973).

Theories of social change began to intersect with the transformations of the welfare state shortly after the middle of the 20th century. Since the 1960s, attempts to interpret the expansion of the functions of the state into the social arena have adopted various approaches. Different schools of thought have been used. Functionalist and Marxist approaches, interpretations of power resources theory, and historical institutionalism have been used in an attempt to interpret the development of social protection measures within the capitalist system.

A first group of theories, governed by functionalist characteristics, sees the development of the welfare state as a mature need of society or of capitalism. This group includes at least three subinterpretations of the transition to the Keynesian welfare state; notably, structural or operational approaches that place an emphasis on (1) industrialization (Flora \& Alber, 1981; Kerr, 1960; Wilensky, 1975); (2) the modernization of society (Hill, 1980; Rostow, 1960); and (3) the needs of mature capitalism (O'Connor, 1973; Rimlinger, 1971 ). A second group draws on other Marxist approaches, such as that of Offe (1984), pointing out that the Keynesian welfare state was consolidated because previous forms of social solidarity (family, church) could no longer meet the needs of the working class within an urbanized society.

A third category of interpretations is the power resources theory. This approach argues that the varying degrees of trade union activity and working-class mobilization produce variations in the morphology of the different welfare states (Korpi, 1983). A fourth school of interpretation is that of historical institutionalism. In terms of social policy, historical institutionalism examines the causal relations for the economic and institutional reforms that led to the formation of the Keynesian welfare state (Skocpol, 1992). 
The welfare state crisis of the 1970s triggered a new phase of social changes that led to the consolidation of the neoliberal welfare state. Different schools of thought have formulated their own interpretations of this social change. A first interpretive approach highlights the emergence of new social risks. According to Taylor-Gooby (2004; Taylor-Gooby et al., 2017), the dynamics of globalization and the transition from an industrial to a postindustrial society, extensive changes in family structure and gender relations, but also the long period of economic recession, high unemployment, and the trend toward demographic aging have created a climate that differs significantly from that of the first postwar decades in which the Keynesian model developed.

A second major category that seeks to explain the phenomenon of the transition to the neoliberal welfare state is the neoinstitutionalism approach. According to neoinstitutionalism, significant social changes, such as those mentioned previously, have weakened the role of the state. Nonetheless, and despite the cuts, the social benefits have shown a relative resilience (Pierson, 2001). A third interpretive approach to the changes that have led to the neoliberal welfare state derives from the power resources theory, with an emphasis on the role of business. The strengthening of corporate power in the new globalized context of strengthening market freedom and shrinking the state has enabled them to further influence social policymaking (Swenson, 2002).

The Great Recession of 2008 is, for many scholars (e.g., McBride et al., 2015; Taylor Gooby et al., 2017), a second phase of social change that has strengthened the neoliberal welfare state. The economic crisis was used as an opportunity for major and profound social changes with a focus on the further residualization of social protection systems and the privatization of social policy. Several different approaches, influenced by neoinstitutionalism, fiscal sociology, and also discourse theory, have formulated their arguments in this context.

Neoinstitutionalism approaches focus on the different varieties of capitalism. Central to this analysis is the growth model that has been adopted by institutions on a global and European scale as well as the impact on national economies (Iversen et al., 2016). The established rules of the institutions have not provided procedures by which national governments can balance the current budget deficits. In addition, there are no institutional means for tackling global imbalances, with the result that different models of capitalist development are reproduced in ways that cause recurring economic problems, such as the recent Great Recession (Iversen \& Soskice, 2013). Other studies with their origins in neoinstitutionalism describe the Great Recession of 2008 as the culmination of fiscal control processes that began with the 1970 oil crisis. These processes, under the influence of neoliberalism, took the form of state policies designed to weaken the framework for the protection of employment and to resolutely rearrange the balance of social forces in favor of the capitalist class (Heyes et al., 2012).

A second category is those interpretations that have the characteristics of fiscal sociology (see Kotsonopoulos, 2016, pp. 223-234). In his book Capitalism Hits the Fan, Richard Wolff (2009) interprets the 2008 crisis as a consequence of the mix of the profit explosion after 1970, the expansion of the debt-driven financial system, and the real estate bubble. The phenomenon of over-indebtedness has been studied by Maurizio Lazzarato (2011). The financial crisis of 2008 was a turning point for the complete transformation from the welfare state to the construction of the indebted man, a goal that has been pursued for four decades by the dominant political forces. Thus, the austerity policies consolidated by the neoliberal political program focus on sharp cuts in social protection systems and government services in general (Lazzarato, 2011). In addition, the study by Wolfgang Streeck (2014) argues that the crisis of 2008 is part of the deep process of restructuring the Keynesian capitalist model that began in the 1970s. The Great Recession of 2008 brought forth this very conflict between the will of the citizens and the markets (Streeck, 2014).

The third interpretive approach focuses on the discourse that has been constructed to legitimize the residual tendency of the welfare state. This interpretation refers to the broader context that has emerged in public discourse on the legitimacy of deregulatory interventions but also to the eloquent content that accompanies them (Hollanders \& Vis, 2013; Vis, 2009). Here, the systemic media, government representatives, and other 
formal or informal actors influencing public opinion are recruited to promote the reduction of social spending as necessary or as interventions that serve to sustain the social protection system in the long run (Petmesidou, 2014).

From these brief remarks, one understands that the relationship between social change and the welfare state is extremely complex. The synthesis of different interpretive projects is considered necessary to make the understanding of the changes that take place at a macroscopic level more feasible. The rest of this manuscript will examine the social changes that occurred in the Greek social security system during the decade of multiple crises (2010-2020). Following the advice of social change scholars (such as Strasser \& Randall, 1981), I will start with the features of the evolution of the social security system in Greece until 2010 so the magnitude of social change can be adequately understood.

\section{Social Change and the Development of the Greek Welfare State}

The development of the Greek welfare state deviates from the development model of the welfare states of Western Europe, as is also the case with the other countries of the European South (Ferrera, 1996). There are thus significant differences in the interpretive approaches, compared to those previously presented. A large part of the historical sociology bibliography attributes this fact to the peculiar development of the Greek social sphere. A central tool for understanding these issues is the concept of dependence, which is seen as a social phenomenon concerning power relations between the Centre and the Periphery. To be precise, the concept relates to the negative effects of capitalist development in the countries of the Periphery and the investigation of internal class structures (Petmesidou-Tsoulouvi, 1984). The welfare state in Greece did not develop in conditions of normalcy and continuity. Its most central body was the social security system, which was typified by profound fragmentation, segmentation, and obvious forms of inequality between social groups (Venieris, 1994).

I will argue that, despite the significant differences in economic, political, social, and cultural parameters that have led to social changes in the Greek welfare state compared to Western European countries, the last decade has seen a process of convergence in terms of a race to the bottom (Kourachanis, 2020). The austerity policies imposed by the economic and, most recently, pandemic crises have resulted in the acceleration of residualization trends and the privatization of social policy (Dimoulas \& Kouzis, 2018). The consequence of the implemented policies is a process of social change that is still evolving to put the Greek welfare state onto the track of the neoliberal political model in an even more intense way.

\section{The Evolution of the Greek Social Security System Until the Great Recession}

During the period of the establishment and development of the Greek social security system, significant deficiencies, weaknesses, and inequalities were observed. The social insurance system has been undermined by fragmentation, the lack of effective social dialogue, political timidity in the face of political costs, misuse of insurance fund reserves and inequalities in privileges, and benefits for different occupational groups. However, the social assistance system was developed in a fragmented manner and very late. In short, the safety net was insufficient (Petmesidou, 2006). Within such conditions, the institution of the family substituted for the multiple shortcomings of state social policy (Ferrera, 1996). The institutional development of the two main pillars of each social security system (social insurance and social assistance) is presented next.

\section{Social Insurance}

From the founding of the Greek state until the interwar period in Greece, social insurance funds were mainly established by occupational unions. The first major state intervention in social insurance was Law 2868/1922, which established the obligation to provide social insurance for employees in urban areas. A decade later, Law 5733/1932 and Law 6298/1934 sought to consolidate insurance policies through the establishment of the 
Social Insurance Institute (IKA). The basic principles laid down for IKA were strongly influenced by the Bismarckian tradition (Venieris, 1994).

After the end of World War II (1940-1944) and the Greek Civil War (1946-1949), the victorious right-wing forces were called upon to develop a plan for the reconstruction of Greek society. Law 1846/1951 reorganized health and unemployment insurance and introduced the obligation for the tripartite financing of IKA with state participation. In 1961, with Law 4169, the Agricultural Insurance Organization (OGA) was established to provide insurance coverage to farmers. OGA benefits were initially based on the Beveridge insurance model, financed by general taxation (Tsalikis, 1967).

The election of the social-democratic government of the Panhellenic Socialist Movement (PASOK) in 1981 brought large increases in pensions and the general development of the social policy of the Greek state. These increases were not part of a broader long-term plan for the sustainability of the insurance system, with the result that its budget deficits multiplied. Since the early 1980 , IKA has faced serious sustainability problems (Venieris, 1994).

The electoral victory of the right-wing party (i.e., New Democracy ) in 1990 led to widespread cuts in social security. In general, privatization efforts were made in all areas of social policy. Law 1902/1990 sought to increase the retirement age, set limits on maximum pensionable earnings, deal with contribution evasion, and increase the required contributions. Law 2084/1992 established a new pension system for those entering the labor market after 1993, with a general retirement age of 65 years.

The second period of PASOK governance (1993-2004) made new attempts to tighten the rules for the receipt of social security benefits. The end result of these efforts, following large protests by the unions in 1999-2001, was Law 3029/2002. This law established the professional insurance funds, which had not previously been foreseen, increased the years of employment to 35 years, set uniform retirement rules, and planned to ensure the financial operation of IKA until 2030.

Law 3655/2008 passed by the New Democracy government was the last such law before the outbreak of the financial crisis. It sought, in essence, to eliminate the bureaucracy of the diverse system of 133 insurance agencies, decrease resource waste and contribution evasion, and reduce the unequal treatment of policyholders by different professional bodies.

\section{Social Assistance}

Until World War II, social assistance services were extremely limited, with strong elements of social control (Petmesidou, 2006, p. 320). A remarkable initiative in the first half of the 20th century was the creation of the Patriotic Foundation for Social Protection and Perception (PIKPA in Greek) in 1914. It was reorganized with Law 1950/1939, which sought to protect motherhood and childhood and the social care of vulnerable groups. In the postwar period, a more organized social assistance policy was pursued with a focus on the establishment of national institutions (such as the National Social Welfare Organization).

The 1980 s saw a desire to reorganize and further develop the Greek social assistance system. Its expansion of beneficiaries, such as the uninsured elderly, needy mothers, and others, could be observed (Petmesidou, 2006). At the same time, in 1983, one of the few milestones of social policy in Greece was established: the National Health System.

The culmination of the reform efforts that began in 1980 was the creation of the National Social Care System (ESKF in Greek) with Law 2646/1998. The ESKF aspired to eliminate the outdated social assistance framework in the country, which was characterized by a dearth of uniform planning, a lack of scientific elaboration of programs, inefficiency in utilizing social spending, poor coordination, and a low-quality volunteer culture as a vehicle to assist welfare actions (Sakellaropoulos, 1999, pp. 289-290). 
Finally, the establishment of the National Center for Social Solidarity in 2003 aimed to coordinate the network of social support services to those parts of the population that were experiencing emergency needs. This Greek initiative was one of the most important projects in the context of social assistance until the onset of the economic crisis.

\section{Social Security System Reforms During the Multiple Crises in Greece (2010-2020)}

The emergence of the economic crisis brought about painful changes in Greek society with a significant upsurge in social problems (Kouzis et al., 2019). According to available Eurostat data (2020), there has been a significant deterioration in social indicators in Greece. Indicatively, the poverty and social exclusion risk rate increased from $27.7 \%$ in 2010 to $35.7 \%$ in 2016 ; the unemployment rate from $7.8 \%$ in 2008 to $24.9 \%$ in 2015 ; the general unemployment rate jumped from $9.6 \%$ in 2009 to $27.5 \%$ in 2013 ; the long-term unemployment rate rose from $3.9 \%$ in 2008 to $18.2 \%$ in 2015 ; the material deprivation rate grew from $21.8 \%$ in 2008 to $40.7 \%$ in 2016; and the housing burden rate for poor households went from $18.1 \%$ in 2010 to $40.9 \%$ in 2016 (Eurostat, 2020).

Social policy is even more essential in difficult and harmful times (Venieris, 2015). In the Greek case, the changes that were promoted were in the opposite direction. As social problems intensified, the social security system underwent changes for the privatization and the residualization of its benefits (Dimoulas \& Kouzis, 2018). Significant reductions in pensions, welfare, and family benefits as well as the weakening of social services were just some of the extensive rearrangements of the Greek social protection system during the crisis (Petmesidou, 2017). These changes are given more fully below.

\section{Social Insurance}

The economic crisis has given rise to a series of deconstructions of the social insurance system. These changes are taking place abruptly, a key trend being consolidating the privatization of the social insurance system by reducing its redistributive texture and strengthening its funded scheme elements. The spirit of the changes in the years of austerity seeks to form a mixed insurance protection economy with the retreat of the public pension system and an increase in contributions and required insurance years (Koumarianos, 2018).

The first phase of insurance reform in the austerity years occurred with Law 3863/2010 for private sector employees and the corresponding Law 3865/2010 for public sector employees. The PASOK government attempted to establish a new framework in the architecture of the insurance system. There were basically three main points of the insurance reform: first, the introduction of uniform rules for all policyholders; second, the new structure of the pension system; and third, the continuation of the project to unify the social insurance institutions.

Law 3918/2011 created the National Organization for the Provision of Health Services (EOPYY in Greek) with the aim of reorganizing the administrative structures of the health system. Despite its unifying logic, several problems arose during its operation for reasons such as the limits on insurance coverage to attempt cost savings and its congenital budget deficits as the debts of the consolidated insurance funds were transferred to it (Economou, 2018). Law 4052/2012 created the Common Auxiliary Insurance Fund, which includes the auxiliary pension funds of the public and private sectors and henceforth operates with individually funded nondefined contribution accounts (NDC). Law 4093/2012 ushered in new changes to retirement age limits, reductions in pensions, and the abolition of Christmas and Easter cash benefits. In particular, for the establishment of a pension right, the general age limit was set at 67 years with a minimum of 15 years of insurance payments. In addition, from January 1, 2013, a general condition of retirement was the completion of 40 years of insurance and being 62 years old. 
The second phase of insurance reform was undertaken by the governing coalition of the Coalition of the Radical Left (SYRIZA in Greek) with the Independent Greeks-National Patriotic Alliance (ANEL in Greek; 2015-2019; a coalition between a radical left party with a populist right-wing party) with Law 4387/2016. This law established the Common Social Insurance Institution (EFKA) into which all insurance institutions were merged. In this way, EFKA is now the only provider of main pensions with uniform rules for all policyholders (even the self-employed). With this same law, the Common Fund of Auxiliary Insurance and Lump sum Benefits (ETEAEP in Greek) was established for the consolidation of all auxiliary insurance funds and lump-sum funds. The same logic applies to uniform contribution rules for all insured persons, uniform rules for the collection of insurance contributions, and the consolidation of pension benefits. EFKA now pays the national and the contributory pension. The national pension, which is funded by the state, is paid to those who have completed at least 15 years of insurance payments. The contributory pension is calculated based on the average monthly salary of the insured individual for the entire duration of their life insurance and is paid by the insurance companies.

The fundamental change in the architecture of the social insurance system reveals at least two major rearrangements. The introduction of a common main pension paid from general taxation establishes a solidarity relationship between citizens, moving away from the solidarity relationship between insured employees. The income level at which it is set reveals that its main purpose is the management of extreme poverty. However, the introduction of notional defined contributions introduces the individual reimbursement and shifts the responsibility for ensuring a decent pension to the insured citizen. In this way, workers who are most vulnerable to the risk of unemployment and/or low-paid and precarious work are the most affected (Koumarianos, 2018).

A new insurance intervention is currently being conceived during the COVID-19 pandemic. The New Democracy government (2019) established a committee of experts headed by Professor Christoforos Pissarides to draft a report with proposals for the country's growth policy. The Pissarides report was published in July 2019 and made proposals for the further reduction of the public character of social insurance. The package of proposals focuses in particular on reducing employee insurance contributions, eliminating the solidarity contribution, developing second (auxiliary) and third (private) social insurance pillars with private savings incentives, and the transition from a distributive to an auxiliary pension-funded system, all of which are central points of the forthcoming insurance reform (Pissarides, 2020).

The period of economic crisis and austerity policies, therefore, brought about structural cuts within the philosophy of the Greek social insurance system. The crisis presented a series of major consolidations of insurance bodies and rules that have been pending for decades to, almost exclusively, reduce pension expenses. The new structure of the insurance system is a vehicle for serving the broader modern goals and orientations of social policy: an assistance-type pension coverage for those in extreme poverty and a funded, individual investment for those who can afford insurance services (Kourachanis, 2021).

\section{Social Assistance}

Within this context of the residualization of social protection during the years of the Greek crisis, the provision of social assistance has undergone significant changes. In general, there has been a further tightening of the criteria for the reimbursement of benefits with extensive cuts in funding. However, the most important measure could be considered the introduction of the basic assistance pension (Matsaganis, 2012), as described previously. Law 3996/2011 tightens the performance criteria of pensioners' social solidarity allowance (EKAS) (Feronas, 2019).

A first, horizontal form of intervention during the economic crisis was implemented in the context of fiscal adjustment programs. Its purpose was to develop urgent intervention measures to mitigate the extreme social consequences of the implementation of the austerity commitments. Characteristic here is the creation of the Social Structures for Immediate Poverty Management, co-financed by the European Social Fund and with 
municipalities and nongovernmental organizations as the implementing bodies. Structures such as social groceries, social clinics, social pharmacies, time banks, homeless shelters, and homeless daycare centers have been established to relieve vulnerable groups from the adverse effects of austerity (Kourachanis, 2015).

At the end of 2014, the implementation of actions by the Food Aid Fund for the Poor (TEVA in Greek) was approved. TEVA is intended to distribute food and basic material assistance and accompanying services (TEVA, 2014, pp. 3, 5-6) for individuals and families living in conditions of extreme poverty. In 2016, community centers were established to act as the core of the expanded one-stop services. Their operation seeks to develop a local reference point for the connection of citizens with all social programs and services implemented in the intervention area (Sakellaropoulos et al., 2019).

The most fundamental change in social assistance in the crisis years has been the institutionalization of the guaranteed minimum income (GMI) (Dimoulas, 2017; Lalioti, 2017). From the limited research efforts to date, it is clear that the GMI is not effective in tackling extreme poverty. On the contrary, it ensures the absolutely necessary material conditions for its beneficiaries to survive, as only the pillar of income support has been fully implemented to date. With such an application, conditions of welfare dependency are quite possible as the beneficiaries tend to remain in the program for a long time without being able to become autonomous from it (Sakellaropoulos et al., 2019).

During the COVID-19 pandemic, the New Democracy government (2019) introduced a new codification of bankruptcy legislation. In the framework of Law 4738/2020, during the bankruptcy process, debts to banks are served first, with absolute priority. Any debts to public organizations and insurance funds are served only secondarily. The request for any out-of-court debt settlement procedure is evaluated by the banks. At the same time, Law 4738/2020 also removes any framework for the protection of the primary residence for overindebted households. In the vast majority of cases, the households whose property is confiscated are provided with the right to rent it for 12 years. The state will provide a partial rent subsidy and there will be a right to repurchase the property at the end of the lease, at a commercial value determined by the banks. Finally, if 3 months' rent goes unpaid, the debtor will be evicted (Papadopoulou \& Kourachanis, 2021).

Social assistance in Greece to this day remains marginalized both in terms of services and income support. The safety net, even before the outbreak of the crisis, was perforated and unprepared to manage its adverse consequences (Feronas, 2018). A range of gaps left some groups vulnerable, such as the long-term unemployed, new entrants to the labor market, precarious workers, the self-employed in need, poor families, people with disabilities, and low-income pensioners (Matsaganis, 2012).

\section{Conclusions}

In this article, I presented the relationship between social change and the welfare state through the examination of the Greek case. This was done with an analysis of the social security system, the backbone of the Greek welfare state. The analysis shows that, despite the significant differences found in the development of the welfare state in Greece compared to the countries of Western Europe, there has been a race to the bottom in recent years.

Based on the literature review, social changes may stem from economic, political, and cultural influences. The shift to the Keynesian model of the welfare state in Western Europe is attributed, among other things, to industrialization, the modernization of capitalist societies, the demands of the working class, and economic and institutional reforms. The changes that led to the rise of the neoliberal welfare state from the 1970s onward are attributed to the impact of new social risks, such as globalization, the postindustrial society, demographic aging and changes in family structure, the weakening of the role of the state, and the strengthening of the role of business. The changes brought about by the Great Recession of 2008 are 
interpreted as the culmination of fiscal constraints that began in the 1970s. In this context, over-indebtedness is used as a vehicle to extend the dominance of the financial system. The promoted changes are legitimized through the construction of a discourse of obligatory and necessary cuts, which lead to the residualization of the neoliberal welfare state.

The social changes that have affected the fluctuations in the Greek social security system have different starting points but converge in their direction with the model of neoliberal residualization of social protection systems. The Greek social insurance system was built on a shaky foundation with inherent weaknesses-the fragmentation of institutions and services, inequalities in access to social benefits for different occupational and social groups, clientelistic networks, the lack of the willpower to make bold reforms in the face of political upheaval, social inequalities, inefficient social spending in tackling poverty, and the distorted and financially unsustainable structure of the insurance system-as well as the weak presence and charitable mentality of social assistance structures.

The reform efforts in the Greek social security system during the period of economic crisis have led to the development of a philosophy of the convergence of the character of social policy with the wider transformations that are occurring in European welfare states. Consolidating a framework of residual welfare policies for the extremely poor and developing a privatized insurance coverage model for those employees who have access to it are central features of modern developments internationally. The economic crisis and its management policies are the vehicle for fulfilling these deregulations that lead to a social policy model that does not guarantee, or serve, the goal of a dignified life for citizens.

The current period of the COVID-19 pandemic leads to a more extreme philosophy of self-protection and individual responsibility and the state's abstention from the management of social problems. This is evident from the ongoing efforts to move to a funded insurance system as well as from the removal of protection for the primary residence in the event of bankruptcy. The developments of the last decade signify the processes of social change with a negative social character that lead only to a further escalation of social inequalities. 


\section{References}

Abel-Smith, B. (1959). Social security. In M. Ginsberg (Ed.), Law and opinion in England in the 2oth century. University of California Press.

Abel-Smith, B., \& Townsend, P. (Eds.) (1984). Social security, the real agenda: The Fabian Society's response to the government's review of social security. Fabian Society.

Abercrombie, N., Hill, S., \& Turner, B. S. (1984). The Penguin dictionary of sociology. Penguin Books Ltd.

Béland, D., \& Waddan, A. (2012). The politics of policy change. Welfare, Medicare, and social security reform in the United States. Georgetown University Press.

Dimoulas, C. (2017). The implementation of the SSI in Greece. Journal of the Hellenic Social Policy Association, 7, 7-24 (in Greek).

Dimoulas, C., \& Kouzis, I. (Eds.) (2018). Crisis and social policy. Deadlocks and solutions. Topos (in Greek).

Economou, C. (2018). The impact of the economic crisis and the memoranda on the Greek health system. In C. Dimoulas \& I. Kouzis (Eds.), Crisis and social policy. Deadlocks and solutions. Topos (in Greek).

Eurostat (2020). Eurostat Database, November 29, 2020, http://ec.europa.eu/eurostat/data/database

Fairclough, N. (1992). Discourse and social change. Polity Press.

Feronas, A. (2018). Social assistance in crisis Greece: The "poor relative" in the vortex of neoliberal austerity. In C. Dimoulas \& I. Kouzis (Eds.), Crisis and social policy. Deadlocks and solutions. Topos (in Greek).

Feronas, A. (2019). Social exclusion and social solidarity in crisis Greece. Topos (in Greek).

Ferrera, M. (1996). The "southern model" of welfare in social Europe. Journal of European Social Policy, 6(1), 17-37. https://doi.org/10.1177/095892879600600102

Flora, P., \& Alber, J. (1981). Modernization, democratization and the development of welfare states in Western Europe. In P. Flora \& A. J. Heidenheimer (Eds.), Development of welfare states in Europe and America. Routledge.

Fouskas, V. K., \& Dimoulas, C. (2013). Greece, financialization and the EU. The political economy of debt and destruction. Palgrave Macmillan.

Giddens, A. (1997). Sociology (3rd ed.). Polity Press.

Heyes, J., Lewis, P., \& Clark, I. (2012). Varieties of capitalism, neoliberalism and the economic crisis of 2008? Industrial Relations Journal, 43(3), 222-241. https://doi.org/10.1111/j.1468-2338.2012.00669.x

Hill, M. (1980). Understanding social policy. Blackwell Publishers.

Hollanders, D., \& Vis, B. (2013). Voters' commitment problem and reforms in welfare programs. Public Choice, 155, 433-448. https://doi.org/10.1007/s11127-011-9872-1

Jimenez, J., Pasztor, E.M., Chambers, R. and Fujii, C.P. (2014), Social Policy and Social Change. Toward the Creation of Social and Economic Justice, London: Sage.

Iversen, T., \& Soskice, D. (2013, June 3). A structural-institutional explanation of the Eurozone crisis [Paper presented at the Political Economy Workshop at the London School of Economics]. http://www.people.fas.harvard.edu/ iversen/PDFfiles/Iversen\&Soskice_euro2015.pdf

Iversen, T., Soskice, D., \& Hope, A. (2016). The Eurozone and political economic institutions. Annual Review of Political Science, 19, 163-185.

Kerr, C., Dunlop, J. T., Harbison, F. H., \& Myers, C. A. (1960). Industrialism and industrial man: The problems of labour and management in economic growth. Harvard University Press. 
Korpi, W. (1983). The democratic class struggle. Routledge \& Kegan Paul.

Kotsonopoulos, L. (2016). The lost consensus. Welfare state, capitalism and democracy. Sakis Karagiorgas Foundation (in Greek).

Koumarianos, E. (2018). The Greek social insurance during the crisis. In C. Dimoulas \& I. Kouzis (Eds.), Crisis and social policy. Deadlocks and solutions. Topos (in Greek).

Kourachanis, N. (2015). Confronting homelessness in Greece during the economic crisis. Social Cohesion and Development, 1O(2), 113-129. https://doi.org/10.12681/scad.9976

Kourachanis, N. (2020). Citizenship and social policy. From post-war development to permanent crisis. Palgrave Macmillan.

Kourachanis, N. (2021). The evolution of social security system in Greece. In M. Żakowska \& D. Domalewska (Eds.), Social security in the Balkans: An overview of social policy in Croatia, Albania, Bosnia and Hercegovina, Greece, Romania and Bulgaria. Vol. 1. Brill Publications.

Kouzis, I., Dimoulas, C., \& Karlaganis, P. (2019). The social impact of memoranda in Greece. GUE/LEFT, Athens: European Parliament.

Lalioti, V. (2017). Minimum guaranteed income. The chronicle of a proposed measure. Gutenberg (in Greek).

Lazzarato, M. (2011). The making of the indebted man: An essay on the neoliberal condition. Semiotext(e).

Matsaganis, M. (2012). Social policy in hard times: The case of Greece. Critical Social Policy, 32(3), 406-421. https://doi.org/10.1177/0261018312444417

May, V. (2011). Self, belonging and social change. Sociology, 45(3), 363-378. https://doi.org/10.1177/0038038511399624

McBride, S., Mahon, R., \& Boychuk, G. (Eds.). (2015). After 'o8: Social policy and the global financial crisis. UBC Press.

McCashin, A. (2019). Continuity and change in the welfare state: Social security in the Republic of Ireland. Palgrave Macmillan.

O'Connor, J. (1973). The fiscal crisis of the state. St. Martin's Press.

Offe, C. (1984). Contradictions of the welfare state. MIT Press.

Papadopoulou, D., \& Kourachanis, N. (2021). The "bankruptcy law" as a dimension of neoliberalism, responsibility and authoritarianism during the Covid-19 pandemic. In A. Kapsalis, E. Koumarianos, \& N. Kourachanis (Eds.), Social policy between authoritarianism and the pandemic COVID-19. Topos (in Greek).

Papatheodorou, C. (2015). Economic crisis, poverty and deprivation in Greece. The impact of neoliberal remedies. In S. Mavroudeas (Ed.), Greek capitalism in crisis: Marxist analyses. Routledge.

Petmesidou, M. (2006). Social care services: "Catching up" amidst high fragmentation and poor initiatives for change. In M. Petmesidou and E. Mossialos (Eds.), Social policy developments in Greece. Ashgate.

Petmesidou, M. (2014). Preface. From the golden age to the age of crisis. In G. Esping-Andersen (Ed.), The three worlds of welfare capitalism. Topos (in Greek).

Petmesidou, M. (2017). Welfare reform in Greece: A major crisis, crippling debt conditions and stark challenges ahead. In P. Taylor-Gooby, B. Leruth, \& H. Chung (Eds.), After austerity. Welfare state transformation in Europe after the Great Recession. Oxford University Press.

Petmesidou-Tsoulouvi, M. (1984). Approaches to the subject of the underdevelopment of the Greek social formation: A critical view. Synchrona Themata, 22, 13-30 (in Greek). 
Pierson, P. (Ed.). (2001). The new politics of the welfare state. Oxford University Press.

Pissarides, C. (2020). Development plan for the Greek economy (in Greek).

Rimlinger, G. (1971). Welfare policy and industrialisation in Europe, America and Russia. Wiley.

Rostow, W. W. (1960). The stages of economic growth: A non-communist manifesto. Cambridge University Press. Sakellaropoulos, Th., Lalioti, V. and Kourachanis, N. (2019), "The Social Impact of the 'Social Solidarity Income' in Greece: A Qualitative Interpretation”, Social Cohesion \& Development, 13(2): pp. 5-20.

Skocpol, T. (1992). Protecting soldiers and mothers: The political origins of social policy in the United States. Harvard University Press.

Smith, A. D. (1973). The concept of social change: A critique of the functionalist theory of social change. Routledge.

Strasser, H., \& Randall, S. (1981). An introduction to theories of social change. Routledge.

Streeck, W. (2014). Buying time: The delayed crisis of democratic capitalism. Verso.

Swenson, P. (2002). Capitalists against markets: The making of labor markets and welfare states in the United States and Sweden. Oxford University Press.

Sztompka, P. (1993). The sociology of social change. Blackwell.

Sztompka, P. (2000). Cultural trauma: The other face of social change. European Journal of Social Theory, 3(4), 449-466.

Taylor-Gooby, P. (2004). The impact of new social risks on welfare states. In P. Taylor-Gooby (Ed.), New risks, new welfare: The transformation of the European welfare state. Oxford University Press.

Taylor-Gooby, P., Leruth, B., \& Chung, H. (Eds.). (2017). After austerity: Welfare state transformation in Europe after the great recession. Oxford University Press.

Tsalikis, G. (1967). The foundation of social insurance in Greece (1834-1934) [Doctoral thesis, The London School of Economics and Political Science].

Venieris D. (1994). The development of social security in Greece, 1920-199o: Postponed decisions [Doctoral thesis, The London School of Economics and Political Science].

Venieris, D. (2015). Social policy. Concepts and relationships. Topos (in Greek).

Vis, B. (2009). Governments and unpopular social policy reform: Biting the bullet or steering clear? European Journal of Political Research, 48, 31-57. https://doi.org/10.1111/j.1475-6765.2008.00783.x

Wilensky, H. (1975). The welfare state and equality: Structural and ideological roots of public expenditures. University of California Press.

Wolff, R. (2009). Capitalism hits the fan: The global economic meltdown and what to do about it. Interlink Publishing Group.

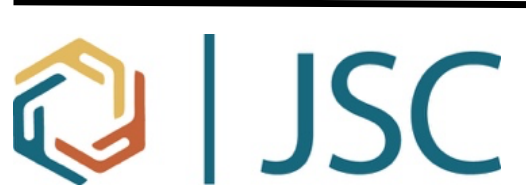

The Journal of Social Change, sponsored by Walden University, welcomes manuscripts focusing on interdisciplinary research in social change that improves the human condition and moves people, groups, organizations, cultures, and society toward a more positive future. 